\title{
Studies on the binding affinity of anticancer drug mitoxantrone to chromatin, DNA and histone proteins Zahra Hajihassan and Azra Rabbani-Chadegani*
}

\author{
Address: Department of Biochemistry, Institute of Biochemistry and Biophysics, University of Tehran, Tehran, Iran \\ Email: Zahra Hajihassan - Hajihassan@ibb.ut.ac.ir; Azra Rabbani-Chadegani* - rabbani@ibb.ut.ac.ir \\ * Corresponding author
}

Published: II March 2009

Journal of Biomedical Science 2009, 16:31 doi:10.1186/1423-0127-16-31

This article is available from: http://www.jbiomedsci.com/content//6/I/3।

(c) 2009 Hajihassan and Rabbani-Chadegani; licensee BioMed Central Ltd.

This is an Open Access article distributed under the terms of the Creative Commons Attribution License (http://creativecommons.org/licenses/by/2.0), which permits unrestricted use, distribution, and reproduction in any medium, provided the original work is properly cited.
Received: 27 October 2008

Accepted: II March 2009

\begin{abstract}
Mitoxantrone is a potent antitumor drug, widely used in the treatment of various cancers. In the present study, we have investigated and compared the affinity of anticancer drug, mitoxantrone, to EDTA-soluble chromatin (SE-chromatin), DNA and histones employing UV/Vis, fluorescence, CD spectroscopy, gel electrophoresis and equilibrium dialysis techniques. The results showed that the interaction of mitoxantrone with SE-chromatin proceeds into compaction/aggregation as revealed by reduction in the absorbencies at 608 and $260 \mathrm{~nm}$ (hypochromicity) and disappearance of both histones and DNA on the gels. Mitoxantrone interacts strongly with histone proteins in solution making structural changes in the molecule as shown by $C D$ and fluorescence analysis. The binding isotherms demonstrate a positive cooperative binding pattern for the chromatin- mitoxantrone interaction. It is suggested higher binding affinity of mitoxantrone to chromatin compared to DNA implying that the histone proteins may play an important role in the chromatin- mitoxantrone interaction process.
\end{abstract}

Mitoxantrone is a synthetic antineoplastic drug, structurally similar to the anthracyclines, widely used as a potent chemotherapeutic agent in the treatment of various cancers such as advanced breast cancer, lymphoma and leukemia [1-3]. Widespread interest in mitoxantrone has arisen because of its apparent lower risk of cardiotoxic effects compared with the naturally occurring anthracyclines $[4,5]$.

Numerous studies on the mechanism of mitoxantrone action indicate that nuclear DNA is the major target for this drug $[6,7]$. The structure of mitoxantrone lacks the amino sugar moiety and tetracyclic ring (A) of anthracyclines but has a planar anthraquinone ring which intercalates between DNA base pairs and the nitrogen-containing side chains bind the negatively charged phosphate groups of DNA $[7,8]$. Binding of mitoxantrone to DNA causes DNA condensation and inhibits DNA replication and RNA transcription [9-11]. Also it is a potent inhibitor of topoisomeraseII, an enzyme known to be important for the repair of damaged DNA and this leads to single and double strand breaks [12].

The binding of mitoxantrone to DNA has been studied in detail [13-15]. However, in the cell nucleus; DNA is compacted into a complex structure built from the interaction of histones with DNA named nucleosomes. These consist of 145 base pairs DNA wrapped around an octamer of core histones. There are 5 main histones: the linker histones of the $\mathrm{H} 1$ family and 4 core histones (H2A, H2B, H3 and $\mathrm{H} 4$ ) which are arranged in an octamer form [16]. How the presence of chromosomal proteins affect and 
modulate the binding of intercalating drugs to DNA, is an important question when trying to understand the mechanism of drug action at the chromatin level. To explore this question, we employed several experiments designed to clarify this question in more detail.

In the present study, we attempted to examine and compare the effect of mitoxantrone on rat liver chromatin, DNA and histone proteins in solution to further understand the mechanism of drug action at the cellular chromatin level. The results provide evidence that mitoxantrone shows different affinity to chromatin, DNA and histones implying that the environment of chromatin plays fundamental role in the drug-DNA interactions.

\section{Materials and methods Materials}

Mitoxantrone hydrochloride $\left(2 \mathrm{mg} / \mathrm{ml}\right.$ in $\mathrm{H}_{2} \mathrm{O}$ ) was purchased from Helale Ahmar, Tehran, Iran (manufactured by Ebewe Pharma Ges.m.b. Austria) stored at $4^{\circ} \mathrm{C}$ in the dark. Before use, it was diluted to desired concentrations with $10 \mathrm{mM}$ Tris- $\mathrm{HCl}$ (pH 7.4) and its concentration was determined spectrophotometrically using a molar extinction coefficient of $19200 \mathrm{M}^{-1} \mathrm{~cm}^{-1}$ at $608 \mathrm{~nm}$. Microccocal nuclease (MNase), proteinase $\mathrm{K}$, ECoR1-Hind III digested DNA marker, cocktail protease inhibitor were from Sigma Chemical Company. Calf thymus DNA (Sigma) was dissolved in $10 \mathrm{mM}$ Tris- $\mathrm{HCl}$ (pH 7.4), dialyzed overnight against the same buffer and its concentration was determined using an extinction coefficient of $20 \mathrm{~cm}^{-1} \mathrm{mg}^{-1}$ at $260 \mathrm{~nm}$. Albino rats weighting of 150-200 gram of either sex were used throughout the experiments.

\section{Preparation of chromatin, DNA and histones}

Nuclei were prepared from rat liver as described elsewhere [17]. All steps were carried out at $4^{\circ} \mathrm{C}$ in the presence of protease inhibitor PMSF at a final concentration of $1 \mathrm{mM}$ or cocktail protease inhibitor $(1 / 100 \mathrm{~V} / \mathrm{V})$. EDTA soluble chromatin was isolated according to the procedure reported before [18] with some modifications. Briefly, the purified nuclei were suspended in digestion buffer $(0.25$ M sucrose, $25 \mathrm{mM} \mathrm{NaCl}, 1 \mathrm{mM} \mathrm{CaCl} 2$ and $10 \mathrm{mM}$ Tris$\mathrm{HCl}(\mathrm{pH} 7.4)$ ) and DNA content was determined by measuring the absorbance at $260 \mathrm{~nm}$. The nuclear suspension at $\mathrm{A}_{260}=100$ was digested with 3 units of microccoccal nuclease $/ \mathrm{mg}$ of DNA at $37^{\circ} \mathrm{C}$ for $10 \mathrm{~min}$. The solution was brought to $10 \mathrm{mM}$ EDTA on ice, centrifuged at 8000 $\mathrm{g}$ for $5 \mathrm{~min}$ and then the chromatin solubilized in 0.25 mM EDTA ( $\mathrm{pH} 8$ ). The chromatin thus prepared designated as EDTA-soluble chromatin (SE-chromatin).

DNA was isolated from the SE-chromatin samples by proteinase $\mathrm{K}$ digestion ( $1 \mu \mathrm{g}$ of enzyme/10 $\mu \mathrm{g}$ of DNA) and phenol-chloroform extraction method. The extracted DNA was then resuspended in $10 \mathrm{mM}$ Tris- $\mathrm{HCl}$ (pH 7.4).
The concentration of DNA in both, the SE-chromatin and purified DNA, were determined spectrophotometrically using an extinction coefficient of $20 \mathrm{~cm}^{-1} \mathrm{mg}^{-1}$ at $260 \mathrm{~nm}$.

Whole histone, consisting of all five histones, was extracted from calf thymus by $0.3 \mathrm{~N} \mathrm{HCl}$ as described by Johns [19] and further purified using DEAE ion exchange chromatography. The whole histone was dissolved in 10 $\mathrm{mM}$ Tris- $\mathrm{HCl}$ ( $\mathrm{pH} 7.3$ ) and after $\mathrm{pH}$ adjustment; the solution was stored at $-20^{\circ} \mathrm{C}$ and used within a month.

\section{UVIVis Spectroscopy}

The SE-chromatin, DNA and histones $[100 \mu \mathrm{g} / \mathrm{ml}$ DNA or histone in $10 \mathrm{mM}$ Tris- $\mathrm{HCl}(\mathrm{pH}$ 7.4)] were incubated individually with appropriate concentrations of mitoxantrone for $45 \mathrm{~min}$ at room temperature in the dark. Control samples containing equal volumes of SE chromatin, DNA and histones in the same buffer were incubated along with the drug treated samples under the same condition.

Mitoxantrone treated and the controls were subjected to spectroscopic analysis using Shimadzo UV-160 spectrophotometer, equipped with quartz cuvettes. The wavelength of $400 \mathrm{~nm}$ was selected to detect the amount of turbidity. After centrifugation at $8000 \mathrm{~g}$ for $1 \mathrm{~min}$, absorbance of the supernatants was recorded using multi $\lambda$ system.

\section{Fluorescence Spectroscopy}

The measurements were performed on a Carry Eclipse fluorescence spectrophotometer equipped with a thermostatically controlled cell holder at ambient temperature. The monochromatic slits were set at $5 \mathrm{~nm}$ to reduce the intensity of the signal depending on the experiment. All samples were made in $10 \mathrm{mM}$ Tris- $\mathrm{HCl}\left(\mathrm{pH} \mathrm{7.3)}\right.$ at $20^{\circ} \mathrm{C}$ and quartz fluorescence cell of $1 \mathrm{~cm}$ path length was used. Protein solution $(5-10 \mu \mathrm{M})$ was titrated with aliquots of mitoxantrone and equilibrated until a steady emission reading was obtained. The accumulated volume of titration was less than $10 \mu \mathrm{l}$, so dilution effect was negligible. The spectra were recorded between 290-410 nm after excitation at $278 \mathrm{~nm}$. Mitoxantrone, histones and amino acid tyrosine were prepared individually in the same buffer and their emission spectra recorded in the same condition and used as a control.

\section{Circular dichroism experiment}

Circular dichroism (CD) experiment was performed using CD spectrometer model 215 (AVIV instruments INC.). The Far-UV CD spectra of histones in $10 \mathrm{mM}$ Tris- $\mathrm{HCl} \mathrm{pH}$ 7.3 and in the absence and presence of various concentrations of mitoxantrone was recorded in the range of 190$260 \mathrm{~nm}$ with a spectral resolution of $1 \mathrm{~nm}$. The scan speed was $20 \mathrm{~nm} / \mathrm{min}$ and the response time was $0.3330 \mathrm{sec}$ with a band width of $1 \mathrm{~nm}$. Quartz cell with a path length 
of $10 \mathrm{~mm}$ was used and all measurements were carried out at $25^{\circ} \mathrm{C}$. Results are expressed as molar ellipticity expressed as $[\theta]$, in $\operatorname{deg} \times \mathrm{cm}^{2} \times \mathrm{dmol}^{-1}$.

\section{Gel electrophoresis}

The supernatants obtained from the interaction of SEchromatin with various concentrations of mitoxantrone were concentrated using Eppendorf concentrator (model 5301 ) and then analyzed on 15\% SDS polyacrylamid gel electrophoresis as described by Laemmli [20]. The gel was stained with coomassie brilliant blue R 250, destained in methanol/acetic acid and photographed.

Agarose (1.5\%) gel electrophoresis was also carried out in TBE buffer [89 mM Tris-borate, 2 mM EDTA (pH 8)] at a constant voltage of $80 \mathrm{~V}$ for $1 \mathrm{~h}$ [21]. The gel was then stained with ethidium bromide $(5 \mu \mathrm{g} / \mathrm{ml}$ in distilled water) and photographed.

\section{Equilibrium dialysis}

SE-chromatin and DNA were prepared in $10 \mathrm{mM}$ Tris-HCl ( $\mathrm{pH}$ 7.4) and dialyzed against the same buffer containing serial concentrations of mitoxantrone using Spectrum Laboratories (USA) dialysis tubing at room temperature. The equilibrium was achieved within $72 \mathrm{~h}$ at $23^{\circ} \mathrm{C}$. The total drug concentration $\left(\mathrm{C}_{\mathrm{t}}\right)$ and the concentration of free drug $\left(\mathrm{C}_{\mathrm{f}}\right)$ in the dialysate were measured directly from the absorbance at $608 \mathrm{~nm}$ before and after dialysis using extinction coefficient of $19200 \mathrm{M}^{-1} \mathrm{~cm}^{-1}$. The amount of bound drug $\left(C_{b}\right)$ was obtained from $C_{b}=C_{t}-C_{f}$. Binding parameters were determined from the plot of $r / C_{f}$ versus $r$ according to Scatchard method [22], where $r$ is the ratio of bound drug to total base pair concentration and $\mathrm{C}_{\mathrm{f}}$ is the amount of free drug. In this presentation, $\mathrm{n}$ (the apparent number of binding sites), is the intercept of the linear region of the binding curve with the horizontal axis. Also $\mathrm{K}$ (apparent binding constant) corresponds to the negative value of the slope of the curve. The Hill coefficient value $\left(\mathrm{n}_{\mathrm{H}}\right)$ was determined from the slope of the $\ln (\mathrm{r} / \mathrm{n}$ r) versus $\ln C_{f}$ according to the Hill equation [23].

\section{Results \\ Mitoxantrone shows higher affinity to chromatin compared to DNA}

An experiment was designed using rat liver soluble chromatin fraction incubated in the presence and absence of the various concentrations of mitoxantrone. Addition of drug to SE-chromatin solution resulted in chromatin aggregation and precipitation which could be detected by monitoring the absorbance at $400 \mathrm{~nm}$ (turbidity). The result is shown in Fig. 1. As is seen, gradual increase in mitoxantrone concentration enhances turbidity of the reaction mixture. Turbidity formation is slow at low concentrations of drug (up to $20 \mu \mathrm{M}$ ), but a sharp absorbance changes is occurred upon increasing drug concentration (between 20 and $40 \mu \mathrm{M}$ ).

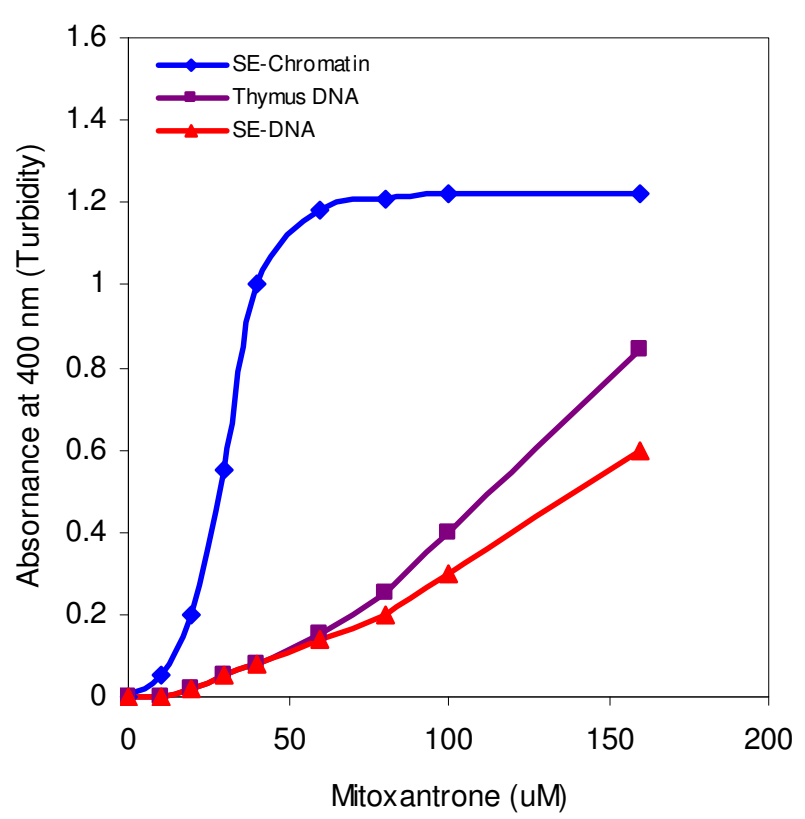

Figure I

Turbidity measurements at $400 \mathrm{~nm}$ of the interaction of various concentrations of mitoxantrone with SE-chromatin (diamond), SE-DNA (triangle) and thymus DNA (square). The reaction was carried out in 10 $\mathrm{mM}$ Tris- $\mathrm{HCl}(\mathrm{pH} 7.5)$ and incubation time was $45 \mathrm{~min}$ at $23^{\circ} \mathrm{C}$. Results are average of 3 individual experiments.

To compare data with the DNA free in solution (in the absence of chromatin proteins), DNA was isolated from such SE-chromatin as described in the method section (designated SE-DNA) and treated with various concentrations of mitoxantrone in the same experimental conditions mentioned for the SE-chromatin. Calf thymus DNA was also used for comparison. The results obtained from turbidity measurement are inserted in Fig. 1. The absorbance changes of both SE-DNA and thymus DNA in the presence of mitoxantrone exhibited similar but not identical binding pattern which differs considerably compared to SE-chromatin- mitoxantrone complex pattern. In the case of both DNAs used, the absorbance changes at 400 $\mathrm{nm}$ is very slow up to $80 \mu \mathrm{M}$ of drug and then changes slightly, thus much higher drug concentration is needed to obtain saturation state.

In the next step, the precipitates were removed by brief centrifugation and the clear supernatants were subjected to UV/Vis spectroscopy measurements. The result of absorbance changes at $260 \mathrm{~nm}$ is shown in Fig. 2. For the SE-chromatin, and at low concentrations of drug ( $\leq 10$ $\mu \mathrm{M})$, a slight increase in the absorbance is observed, but at higher drug values the absorbance is considerably decreased and drops to zero at $40 \mu \mathrm{M}$ of mitoxantrone. Whereas in the case of thymus DNA and SE-DNA, the 


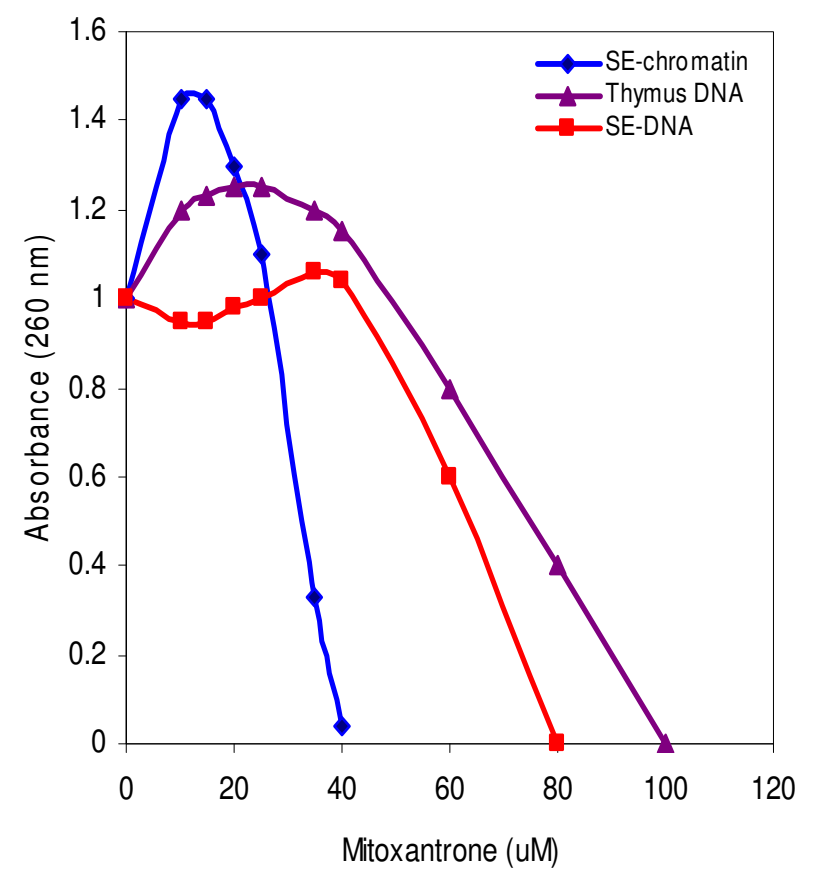

Figure 2

Absorbance changes at $260 \mathrm{~nm}$ of the supernatants obtained from the interaction of mitoxantrone with SE-chromatin (diamond), SE-DNA (triangle) and calf thymus DNA (square). Experimental condition was the same as described in figure I.

absorbance changes at $260 \mathrm{~nm}$ occurs beyond this range (80 and $100 \mu \mathrm{M}$ of mitoxantrone respectively).

\section{Mitoxantrone binds to histones and DNA as analyzed on gel electrophoresis}

In order to obtain information about the possible effect of mitoxantrone on SE-chromatin components, the supernatants obtained from the interaction of mitoxantrone with the chromatin were analyzed on agarose and SDS polyacrylamide gel electrophoresis (Fig. 3). On the SDS gel (Fig $3 \mathrm{~A}$ ), in the absence of mitoxantrone, the proteins released from the chromatin into solution are mostly core histones and a trace of histone $\mathrm{H} 1$ (lane 2) as analyzed parallel to the thymus histones (lane 1). This spontaneous release of proteins has also been observed by Bartkowiak [24] and represents the background of the experiment. In the presence of mitoxantrone and at low concentrations $(<20 \mu \mathrm{g} /$ $\mathrm{ml})$, the proteins pattern is very similar to the control but at higher concentrations $(>20 \mu \mathrm{g} / \mathrm{ml})$, induce chromatin compaction and tends the histones to be un-extractable from the mitoxantrone treated samples leading to their disappearance on the gel (Fig. 3A lanes 5-7).

Moreover, electrophoresis of DNA extracted from the mitoxantrone treated samples and the control, shown in
A
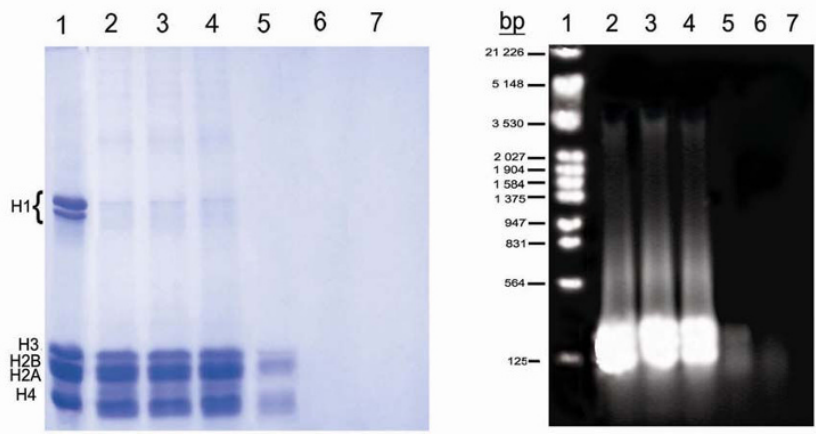

Figure 3

A: 15\% SDS gel electrophoresis of the supernatants obtained from the interaction of various concentrations of mitoxantrone with SE-chromatin. Lanes 2-7 are $0,10,20,30,40$ and $60 \mu \mathrm{M}$ of mitoxantrone respectively. Lane I, calf thymus histones as a standard. B: Agarose gel of DNA extracted from the supernatants. Lane I, EcoRI DNA marker. Lanes 2-7 are the same as in gel A. Number of experiments was 3 .

Fig 3B, demonstrates that gradual increase in drug concentration removes more DNA from the reaction mixture.

\section{Cooperative binding of mitoxantrone to chromatin}

The binding isotherm obtained from the equilibrium dialysis experiment is shown in Fig. 4. The Scatchard plot of the binding of mitoxantrone to SE-chromatin exhibits a cooperative binding behavior, as illustrated by the positive slope observed in the low $r$ regions of the binding iso-

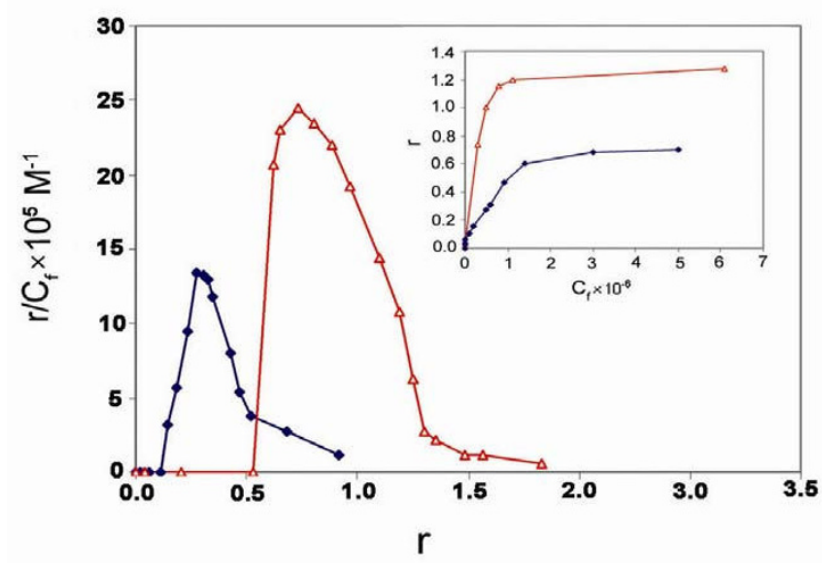

Figure 4

Scatchard plots of the binding of mitoxantrone to SE-chromatin (diamond) and DNA (triangle) carried out in $10 \mathrm{mM}$ Tris- $\mathrm{HCl}$ pH 7.4 for 72 hours at $25^{\circ} \mathrm{C}$. Results are means of 3 individual experiments. 
therm. The curve reaches a maximum at a value of $r=0.27$ and decrease in the slope is observed at higher $r$ values. Drawing $r$ versus $C_{f}$, as shown in the insert of Fig 4, clearly demonstrates a sigmoid curve, that is, as $C_{f}$ increases, $r$ rises rapidly and then levels off, indicating that the system approaches to equilibrium or saturation. The binding of mitoxantrone to chromatin represents a binding constant of $\mathrm{k}=7.1 \times 10^{6} \mathrm{M}^{-1}$ and drawing $\ln \mathrm{r} / \mathrm{n}$-r against $\ln \mathrm{C}_{\mathrm{f}}$ gives a straight line with a slope of the $\mathrm{n}_{\mathrm{H}}$ (Hill coefficient) which was 3 , confirming the positive cooperative binding of drug to chromatin.

The binding isotherm of DNA is also given in Fig. 4. It also exhibits cooperative binding pattern with a binding constant of $k=5.0 \times 10^{6} \mathrm{M}^{-1}$ and $\mathrm{n}_{\mathrm{H}}$ value of 1.9. The result clearly demonstrates lower binding affinity of mitoxantrone to DNA compared to chromatin. The result is in agreement with the cooperative binding of mitoxantrone to DNA reported previously [25].

\section{Mitoxantrone also interacts with the histones free in solution}

Absorbance in the UV/Vis region has been successfully used for the analysis of antracyclines-linker histones interactions $[26,27]$. In this study, the purified histone proteins were incubated in the presence and absence of various concentrations of mitoxantrone and then absorbance changes were monitored at 608 and $210 \mathrm{~nm}$. Figure $5 \mathrm{~A}$ shows the absorbance changes of the histones as a function of drug concentration. As is seen, the absorbance at $210 \mathrm{~nm}$ is considerably decreased upon addition of
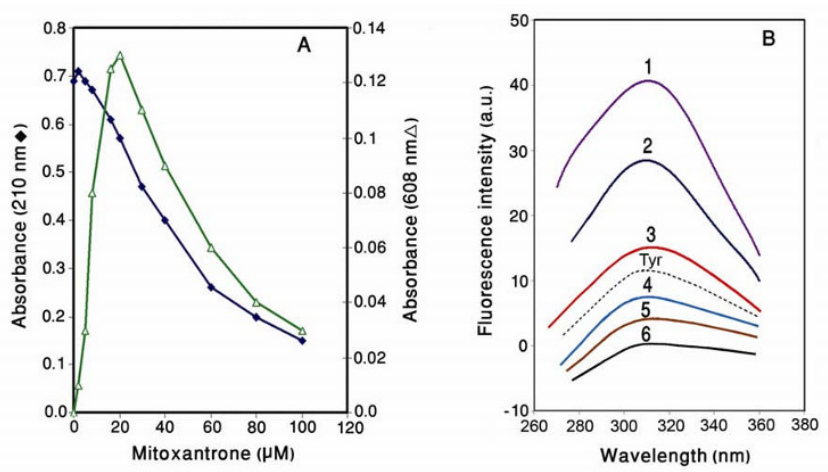

Figure 5

A) Absorbance changes of histones upon mitoxantrone binding. The reaction was carried out in $10 \mathrm{mM}$ Tris- $\mathrm{HCl} \mathrm{pH} 7.3$ at $23^{\circ} \mathrm{C}$. B) Fluorescence emission spectra of the histones in the presence and absence of various concentrations of mitoxantrone. All samples were prepared in $10 \mathrm{mM}$ Tris - $\mathrm{HCl}(\mathrm{pH} \mathrm{7.3)}$ and incubation time after drug addition was 20 minutes. Excitation was at $278 \mathrm{~nm}$. Spectra $\mathrm{I}-6$ are $0,10,20,30,40$, and $60 \mu \mathrm{M}$ of mitoxantrone respectively. Tyr: tyrosine spectrum given for comparison. mitoxantrone. This absorbance reduction is also observed in the pattern of $480 \mathrm{~nm}$ which is exclusively related to the wavelength of mitoxantrone. The results indicate that drug molecules inter the sites of histones, which are active in electron excitation.

The fluorescent emission spectra obtained from the interaction of mitoxantrone with the histones is also shown in Fig 5B. Histones, in the absence of mitoxantrone exhibit emission spectra in the position corresponding to tyrosine emission with a maximum intensity at $305 \mathrm{~nm}$ (fluorescence emission spectra of tyrosine has also been provided for comparison). Addition of mitoxantrone to the histone solution reduces the fluorescence intensity of the histones without any red shift in the emission maxima $\left(\mathrm{I}_{\max }\right)$ as drug concentration is increased. This clearly implies that the binding of mitoxantrone to histones is dependent on their accessibility to the environment.

To obtain further information about the binding of mitoxantrone to histone proteins, we compared the secondary structure of the intact and histone- mitoxantrone complex in the same experimental condition. As is shown in Fig. 6, histones display a CD spectrum with negative extremes at 209 and $220 \mathrm{~nm}$ (the former more intense); whereas, mitoxantrone treatment caused a significant decrease in the intensity of the peaks, especially at 209

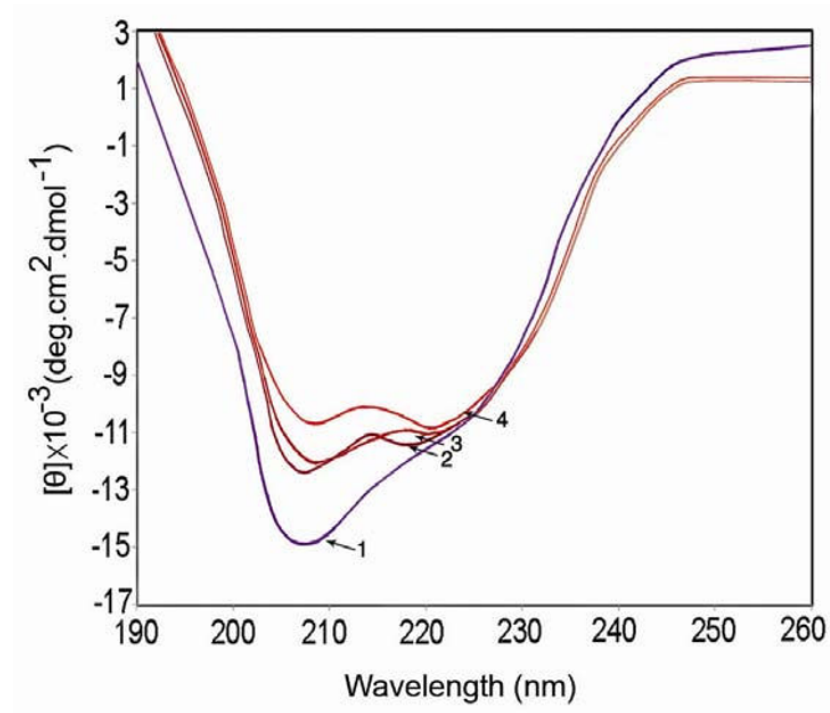

Figure 6

Far UV CD spectra of the histones in $10 \mathrm{mM}$ Tris$\mathrm{HCl}$ at $\mathrm{pH} 7.3$ in the absence and presence of mitoxantrone. Each spectrum was obtained at $25^{\circ} \mathrm{C}$ with a $10 \mathrm{~mm}$ path length cell. I-4 are $0,10,20$ and $40 \mu \mathrm{M}$ of mitoxantrone respectively. All necessary corrections were made for background absorption. 
$\mathrm{nm}$, which implies that, the secondary structure of the protein is perturbed upon drug binding.

\section{Discussion}

Mitoxantrone is an anthracycline analog with potent antineoplastic activity and is distinctly different from doxorubicin in its cytotoxicity to leukemia cells [28]. Numerous studies on the binding of mitoxantrone to DNA have been undertaken and all indicate that it exerts its biological function by intercalation and also electrostatic cross-links within DNA to stabilize the binding $[7,8]$. In the cell nucleus, DNA is complexed with the histone proteins making a defined structure known as nucleosome [16], the structure that has been considered as a tool for the study of genome function in cancer [29]. Therefore the interaction of mitoxantrone with this nucleoprotein complex and its individual components, will clarify the real mechanism of drug action in the cell nucleus.

Although several attempts have been made to understand the mechanism of mitoxantrone action $[13,14,30]$, the environment of nucleic acids in the cell nucleus, especially DNA-protein complex, may significantly modulate the interaction. Despite the presence of numerous published papers on the interaction of mitoxantrone with DNA, to date, the effect of mitoxantrone on chromatin has not been fully understood. In fact, this is the first paper demonstrating the effect of mitoxantrone on chromatin and histones protein (in the absence of DNA) in solution.

Our results suggest that mitoxantrone recognizes the chromatin structure with higher affinity than free DNA. Slight increase in absorbance at $260 \mathrm{~nm}$ announces induction of chromatin unfolding at very low concentration of mitoxantrone $(<10 \mu \mathrm{M})$, however, at higher concentrations the interaction of mitoxantrone with chromatin is accompanied by chromatin compaction/aggregation. The binding of mitoxantrone to chromatin produces a very compact structure that prevents the release or extraction of histone proteins from such drug treated chromatin. Higher affinity of mitoxantrone to chromatin is also confirmed by the results obtained from the binding isotherms. Although the binding is positive cooperative for both DNA and chromatin, but $\mathrm{K}$ values are different. Moreover, mitoxantrone strongly binds to histone proteins in solution, and upon drug action, their secondary structure is reduced. Fluorescence emission spectra exhibits quenching of mitoxantrone with tyrosine chromophores of the histones which are mainly located in their globular domain. Severe binding of mitoxantrone to histones implies that apart from DNA, histone proteins are also a good candidate for mitoxantrone action at the chromatin level; however, the mode of interaction is still unknown.
From the results it also seems that the behavior of mitoxantrone -chromatin interaction differs considerably from the interaction of anthracycline anticancer drugs such as daunomycin and Adriamycin with chromatin. The anthracyclines preferentially bind to less condensed structure of chromatin and the order is DNA >chromatinH1>chromatin [31,18], whereas in the case of mitoxantrone, the affinity of drug to chromatin is higher than to DNA.

In cancer cells, double stranded DNA is also associated with histone proteins making nucleosomes, but because of genetic or epigenetic changes of chromatin, the structure is more relaxed and loose compared to normal cells [32]. This implies that, in cancer cells, mitoxantrone also preferentially binds to nucleosome structure or partially histone free DNA rather than DNA completely free of histone (naked DNA). This is confirmed by our founding that mitoxantrone shows strong affinity to histone proteins. Although Oliveira Brett et al. (1998) have suggested preferential interaction of mitoxantrone with single stranded DNA using acidic condition [33]; we can not speculate this phenomenon which needs extensive work to be clarified.

Taking all together, it is finally concluded that mitoxantrone binds to chromatin and produces a compact structure, the statement which is in good agreement with the anticancer activity of the drug which inhibits DNA and RNA synthesis $[10,11]$. The results come in support of the notion that the protein component of chromatin can also be considered as a target for the activity of this antitumor drug. Whether mitoxantrone interacts directly with the histone proteins or cross linking occurs between the DNA and histones is still unknown. Further insights into the mechanism of mitoxantrone action at the chromatin level especially the real binding sites on histone proteins remain to be elucidated.

\section{Abbreviations}

MNase: micrococcal nuclease; EDTA: ethylenediaminotetraacetic acid; PMSF: phenylmethylsulphonylfloride; SDS: sodium dodecyl sulphate; SE-Chromatin: EDTA Soluble Chromatin.

\section{Competing interests}

The authors declare that they have no competing interests.

\section{Authors' contributions}

Authors AR (as a PhD student supervisor) and ZH (as a PhD student), both have made substantial contributions to conceptions of design, acquisition, analysis and interpretation of data. Also the authors have been involved in drafting the manuscript, revising and approval of the final version to be published. 


\section{Acknowledgements}

The work was financially supported by the grant of the University of Tehran to AR.

\section{References}

I. Holmes FA, Yap HY, Esparza L, Buzdar AU, Hortobaqui GN, Blumenschein GR: Mitoxantrone, cyclophosphamid and 5-fluorouracil in the treatment of hormonally unresponsive metastatic breast cancer. Semin Oncol 1984, I I:28-31.

2. Velasquez WS, Lew D, Grogan TM, Spiridonidis CH, Balcerzak SP, Dakhil SR, et al.: Combination of fludarabine and mitoxantrone in untreated stages III and IV low-grade lymphoma. J Clin Oncol 2003, 2 I: 1996-2003.

3. Thomas X, Archimbaud E: Mitoxantrone in the treatment of acute myelogenous leukemia. Hematol Cell Ther 1997, 39:63-74.

4. White RJ, Durr FF: Development of mitoxantrone. Invest New Drugs 1985, 3:85-93.

5. Koutinos G, Stathopoulos GP, Dontas I, Perrea-Kotsarolis D, Couris $E$, Kararannacos PE, et al: The effect of doxorubicin and its analogue mitoxantrone on cardiac muscle and on serum lipids: an experimental study. Anticancer Res 2002, 22:8I5-20.

6. Feofano A, Sharonov S, Kudelina I, Fleury F, Nabiev I: Localization and molecular interaction of mitoxantrone within living K562 cells as probed by confocal spectral imaging analysis. Biophys J 1997, 73:3317-3327.

7. Lown JW, Morgen AR, Yen SF, Wang YH, Wilson DW: Characteristics of the binding of the anticancer agent's mitoxantrone and ametantrone and related structures to deoxyribonucleic acids. Biochemistry 1985, 24:4028-4035.

8. Krishnamoorthy CR, Sau-Fong Y, Smith JC, Lown JW, Wilson WD: Stopped-flow kinetic analysis of the interaction of anthraquinone anticancer drugs with calf thymus DNA, poly [d (GC)].poly [d (G-C)], and poly [d (A-T)].poly [d (A-T)]. Biochemistry 1986, 25:5933-5940.

9. Kapuscinski J, Darzynkiewicz Z: Relationship between the pharmacological activity of antitumor drugs ametantrone and mitoxantrone (novatrone) and their ability to condense nucleic acids. Proc Nat Acad Sci USA 1986, 83:6302-6306.

10. Nishio A, Uveki EM: Cellular uptake and inhibition of DNA synthesis by dihydroxy anthraquinone and two analogues. Cancer Res 1983, 43:1951-1956.

II. Chiang SY, Azizkhan JC, Boorman TA: A comparison of DNAbinding drugs as inhibitors of E2F I and SP I-DNA complexes and associated gene expression. Biochemistry 1998, 37:3109-31|15.

12. Capranico G, Isabella PD, Tinelli MB, Zunino F: Similar sequence specificity of mitoxantrone and VM-26 stimulation of in vitro DNA cleavage by mammalian DNA topoisomerase II. Biochemistry 1993, 32:3038-3046.

13. Kapuscinski J, Darzynkiewicz Z: Interaction of antitumor agent's ametantrone and mitoxantrone (novatrone) with doublestranded DNA. Biochm Pharmacol 1985, 34:4203-42। 3.

14. Parker BS, Buley T, Evison BJ, Cutts SM, Neuman GM, Iskander MN, et al:: A molecular understanding of mitoxantrone-DNA adducts formation: effect of cytosine methylation and flanking sequence. J Biol Chem 2004, 279: 188|4-18823.

15. Li N, Ma Y, Yang C, Guo L, Yang X: Interaction of anticancer drug mitoxantrone with DNA analyzed by electrochemical and spectroscopic methods. Biophys Chem 2005, I I 6: 199-205.

16. Bradbury EM, Van Holde KE: Chromatin structure and dynamics: A historical perspective in chromatin structure and dynamics: State of the art. Edited by: Zlatanova J, Leuba SH. Elsevier, Amesterdam, The Netherlands; 2004.

17. Burgoyne LA, Waqar MA, Atkinson MR: Calcium-dependent priming of DNA synthesis in isolated rat liver nuclei. Biochem Biophys Res Commun 1970, 39:254-259.

18. Rabbani A, Iskander M, Ausio J: Daunomycin-induced unfolding and aggregation of chromatin. J Biol Chem 1999, 274: $1840 \mid$-18406.

19. Johns EW: Studies on histone: Preparative methods for histone fraction from calf thymus. Biochem J 1964, 92:55-59.

20. Laemmli UK: Cleavage of structural proteins during the assembly of the head of bacteriophage T4. Nature 1970, 227:680-685.
21. Sambrook J, Fritsch EF, Maniatis T: In Molecular Cloning: A Laboratory Manual. Cold Spring Harbor Laboratory Press, Cold Spring Harbor, N.Y; 1989.

22. Scatchard G: The attraction of proteins for small molecules and ions. Ann N Y Acad Sci 1949, 51:660-672.

23. Freifelder DM: Physical biochemistry, application to biochemistry and molecular biology. second edition. Freeman press, New York; 1982.

24. Bartkowiak J, Kapuscinski J, Melamed MR, Darzynkiewicz Z: Selective displacement of nuclear proteins by antitumor drugs having affinity for nucleic acids. Proc Natl Acad Sci USA 1989, 86:5I5I-5I54.

25. Rosenberg LS, Carvlin MJ, Krugh TR: The antitumor agent mitoxantrone binds cooperatively to DNA: evidence for heterogeneity in DNA conformation. Biochemistry 1989, 25:1002-1008.

26. Rabbani A, Abdosamadi S, Sari-Saraf N: Affinity of anticancer drug daunomycin to core histones in solution: comparison of free and cross-liked proteins. Acta Pharmacol Sin 2007, 28:731-737.

27. Zahraei Z, Rabbani-Chadegani A: A comparison of the effect of anticancer drugs, idarubicin and adrimycin on soluble chromatin. Eur J Pharmacol 2007, 575:28-33.

28. Faulds D, Balfour JA, Chrisp P, Langtry HD: Mitoxantrone: A review of its pharmacodynamic and pharmacokinetic properties and therapeutic potential in the chemotherapy of cancer. Drugs 1991, 41:400-49.

29. Umov FD: Chromatin as a tool for study of genome functions in cancer. Ann N Y Acad Sci 2003, 983:5-21.

30. Fox KR, Waring MJ, Brown JR, Neidle S: DNA sequence preferences for the anti-cancer drug mitoxantrone and related anthraquinones revealed by DNase I footprinting. FEBS Lett 1986, 202:289-294.

31. Chaires JB, Dattagupta N, Crothes DM: Binding of daunomycin to calf thymus nucleosomes. Biochemistry 1983, 22:284-292.

32. He S, Dunn KL, Espino PS, Drobic B, Li L, Yu J, Sun JM, Chen HY, Pritchard S, Davie JR: Chromatin organization and nuclear microenvironments in cancer cells. J Cell Biochem 2008, 104:2004-20I5.

33. Oliveira Brett AM, Macedo TRA, Raimundo D, Margues MH, Serrano SHP: Voltammetric behaviour of mitoxantrone at a DNAbiosensor. Biosensors Bioelectronics 1998, I3:86 I-867.

\section{Publish with Bio Med Central and every scientist can read your work free of charge}

"BioMed Central will be the most significant development for disseminating the results of biomedical research in our lifetime. "

Sir Paul Nurse, Cancer Research UK

Your research papers will be:

- available free of charge to the entire biomedical community

- peer reviewed and published immediately upon acceptance

- cited in PubMed and archived on PubMed Central

- yours - you keep the copyright 